\title{
MENINGKATKAN NILAI-NILAI AGAMA PADA ANAK USIA DINI MELALUI PEMBINAAN AKHLAK
}

\author{
Abdurrahman \\ Institut Keguruan dan Ilmu Pendidikan (IKIP) Mataram \\ E-mail: abdurbanyu50@gmail.com
}

\begin{abstract}
Abstrak : Penelitian ini memiliki latar belakang bahwa penanaman nilai-nilai agama pada anak merupakan wahana pembentukan manusia menjadi sosok paripurna yang berakhlak terpuji, bermoral baik dan tentunya bertakwa kepada Allah SWT. Penanaman nilai-nilai agama dalam hal ini sangat penting untuk di berikan sejak dini terutama dalam melibatkan anak-anak sebagai generasi penerus bangsa yang mampu memberikan sumbangsih berarti bagi bangsa dan Negara.Penelitian ini merupakan penelitian kepustakaan (library research), dengan objek penelitian jurnal tentang penanaman nilai-nilai agama dan pembinaan akhlak serta didukung oleh beberapa jurnal dan buku lainnya.Penelitian ini fokus kepada pembinaan akhlak yang diberikan kepada anak dalam membantu meningkatkan nilai-nilai agama pada anak.Hasil penelitian ini menunjukkan bahwa nilai-nilai agama akan lebih efektif di ajarkan kepada anak usia dini melalui pembinaan akhlak yang baik.
\end{abstract}

Kata kunci: nilai-nilai agama, pembinaan akhlak

Title: Increasing Religion Values In Age Children In Early through Administration Author: Abdurrahman

\begin{abstract}
This study has a background that the planting of religious values in children is a vehicle for the formation of human beings to become a plenary figure who has a noble character, good morality and of course fearful of Allah SWT. The planting of religious values in this matter is very important to be given early on, especially in involving children as the next generation of the nation who are able to contribute meaningfully to the nation and the State. This research is a library research, with the object of journal research about the planting of religious values and moral formation and supported by several other journals and books. This research focuses on moral development given to children in helping to improve religious values in children. The results of this study indicate that religious values will be more effectively taught to childhood through good moral formation.
\end{abstract}

Keywords: religious values, moral formation. 


\section{Pendahuluan}

Pendidikan saat ini menghadapi tantangan besar sebagai akibat dari arus globalisasi, sehingga berbagai upaya perlu dilakukan agar peserta didik kelak mampu menghadapi tantangan hidup.Pendidikan anak pertama kali di peroleh dari lingkungan keluarga terutama dari kedua orangtuanya.

Pendidikan Islam dapat diartikan sebagai bimbingan terhadap pertumbuhan rohani dan jasmani menurut ajaran Islam dengan hikmah mengarahkan, mengajarkan, melatih, mengasuh dan mengawasi berlakunya semua ajaran Islam hal ini mengandung pengertian usaha mempengaruhi jiwa anak didik melalui proses setingkat demi setingkat menuju tujuan yang ditetapkan, yaitu "menanamkan nilai-nilai agama serta melakukan pembinaan akhlak sehingga terbentuklah manusia yang berpribadi dan berbudi luhur sesuai ajaran Islam. Dalam Surah An-Nahl ayat 78 yang artinya "Dan Allah mengeluarkan kamu dari perut ibu-ibumu (ketika itu) kamu tidak mengetahui sesuatupun dan Allah menjadikan bagimu pendengaran dan penglihatan serta hati.

Adapun hal-hal yang dapat kita lakukan dalam mendidik anak agar anak dapat menghadapi kemajuan zaman dan mampu menghancurkan kemaksiatan maka dapat kita lakukan dengan cara: kita harus mampu mendidik anak kita higga mereka menjadi cerdas; anak-anak harus kita didik dengan kebenaran filsafat dalam makna yang selas-luasnya; kita harus mendidik anak-anak kita dengan kebenaran Al-Qur'an. Dengan kata lain pendidikan akhlak terutama pendidikan akhlak islami wajib diberikan kepada anak sejak usia dini sebagai bentuk tanggung jawab moral orang tua terhadap anak, disamping pengharapan menciptakan generasi yang berprilaku baik (berakhlak mulia) demi kenyamanan, kedamaian dan kebahagian baik dunia maupun akhirat.

Ibnu Qayyim (dalam Muh. Suwaid 2003:19), anak akan tumbuh menurut apa yang di biasakan oleh pendidiknya ketika kecil. Jika sejak kecil anak terbiasa marah, keras kepala, tergesa-gesa dan mudah mengikuti hawa nafsu, serampangan, tamak dan seterusnya, maka akan sulit baginya untuk memperbaiki 3 dan menjauhi hal-hal itu ketika dewasa. Seperti yang kita ketahui bahwa seorang anak dilahirkan dalam keadaan fitrah tanpa noda dan dosa, seperti sehelai kain putih yang belum mempunyai motif dan warna. Oleh karena itu, orangtualah yang akan memberikan warna terhadap kain putih tersebut. Hal ini sesuai dengan hadits Nabi Saw: ("Setiap anak dilahirkan dalam keadaan fitrah, maka orangtuanyalah yang menjadikanya sebagai Yahudi, Nasrani atau Majusi" ( H.R. Bukhori).

Pendidikan merupakan suatu kebutuhan yang sangat penting bagi kehidupan.Pendidikan adalah jembatan untuk meningkatkan kualitas sumber daya manusia. Pendidikan dapat dilakukan dengan usaha sadar dan terencana untuk mewujudkan suasana belajar serta proses pembelajaran agar peserta didik secara aktif mengembangkan potensi dirinya untuk memiliki kekuatan spiritual kegamaan, pengendalian diri, kepribadian, 
kecerdasan akhlak mulia, serta keterampilan yang diperlukan dirinya, masyarakat, bangsa dan negara. Rumusan Pasal 3 UU No. 20 Tahun 2003 tentang Sistem Pendidikan Nasional secara tegas menyebutkan bahwa pendidikan nasional berfungsi mengembangkan kemampuan dan membentuk karakter serta peradaban bangsa yang bermartabat dalam rangka mencerdaskan kehidupan bangsa. Dalam konteks demikian sekolah merupakan lembaga paling penting dalam mendukung tercapainya fungsi pendidikan itu.Sekolah dapat mengembangkan segenap kemampuan siswa dan membentuk karakter mereka.Sekolah memiliki tanggung jawab moral untuk mendidik anak agar cerdas dan berkarakter positif.

Hal ini menjelaskan bahwa setiap anak yang dilahirkan pada dasarnya dalam keadaan suci tanpa mengetahui apapun akan tetapi anak sudah dibekali dengan pendengaran, penglihatan dan juga hati sehingga ini dapat dikatakan potensi yang dibawanya sejak lahir untuk dapat dikembangkan setelah dilahirkan ke dunia. Dalam pengembangan potensi yang ada pada anak diperlukan didikan yang tentuanya sesuai dengan nilai-nilai atau norma-norma yang ada dan yang terpenting juga sesuai dengan kemampuan yang dimiliki oleh anak.Islam memandang keluarga sebagai lingkungan atau milliu yang pertama bagi individu, dan dalam keluargalah pendidikan yang pertama kali dapat dilangsungkan artinya orangtua mendidik, membimbing dan mengajari akhlak-akhlak yang baik serta sejak dini pula orangtua mulai mengawasi pertumbuhannya dengan cermat dan bijaksana sesuai dengan tuntutan pendidikan Islam.

Dari uraian di atas dapat disebut bahwa tujuan pendidikan anak usia dini dalam pandangan Islam adalah memelihara, membantu pertumbuhan dan perkembangan fitrah manusia yang dimiliki oleh anak, sehingga jiwa anak yang lahir dalam kondisi fitrah tidak terkotori oleh kehidupan duniawi. Atau dengan kata lain bahwa pendidikan anak usia dini dalam pendidikan Islam bertujuan untuk menanamkan nilai-nilai keIslaman kepada anak sejak dini, sehingga dalam perkembangan anak selanjutnya menjadi manusia muslim yang kaffah, yang beriman dan bertaqwa kepada Allah SWT. Hidupnya dapat terhindar dari kemaksiatan, dan dihiasi dengan ketaatan dan kepatuhan serta oleh amal soleh yang tiada hentinya. Kondisi seperti inilah yang dikehendaki oleh pendidikan Islam, sehingga kelak akan mengantarkan peserta didik pada kehidupan yang bahagia di dunia maupun di akhirat.

Selain itu juga pada saat usia anak sudah memasuki 4 tahun maka anak sudah dapat mengikuti pendidikan anak usia dini dengan bimbingan oleh para pendidik. Dalam hal ini ada beberapa konsep pendidikan anak usia dini antara lain; kurikulum dan materi pendidikan anak usia dini dalam perspektif pendidikan Islam, konsep pengajaran yang tepat bagi anak serta metode yang tepat pula. Sebagai anak manusia, sesungguhnya Allah telah melengkapi seseorang anak dengan seperangkat kemampuan yang telah tertanam pada diri manusia berupa sejumlah kemampuan, seperti kemampuan dalam perkembangan moral dan etika, juga kemmapuan dalam perkembangan pribadi, sosial dan kemasyarakatan.Potensi itulah yang 
harus ditangkap oleh para orangtua dan guru, untuk selanjutnya dikembangkan ke arah yang positif. Anak dengan sentuhan pendidikan ini akan menjadi manusia yang bermoral, bermartabat dan mampu menjadi manusia yang mencapai kemuliaan dalam kehidupannya sesuai dengan kodratnya. Berdasarkan latar belakang di atas, maka dapat dibuat beberapa rumusan masalah sebagai berikut: 1)apa pengertian dari pembinaan akhlak pada anak usia dini, 2) bagaimana melakukan pembinaan akhlak.

\section{Metode Penelitian}

Metode penelitian yang di gunakan peneliti adalah metode penelitian kepustakaan (library research), dengan objek penelitian jurnal tentang penanaman nilai-nilai agama dan pembinaan akhlak serta didukung oleh beberapa jurnal dan buku lainnya.Penelitian ini fokus kepada pembinaan akhlak yang diberikan kepada anak dalam membantu meningkatkan nilainilai agama pada anak. Hasil penelitian ini menunjukkan bahwa nilai-nilai agama akan lebih efektif di ajarkan kepada anak melalui pembinaan akhlak yang baik.

Penelitian kepustakaan (Library Research) juga sering disebut dengan istilah penelitian literature menurut Noeng Muhadjir, penelitian kepustakaan itu lebih memerlukan olahan filosofis dan teoritis daripada uji empiris dilapangan (Noeng Muhadjir, 1996:169). Karena sifatnya teoritis dan filosofis, penelitian kepustakaan ini sering menggunakan pendekatan filosofis (philosophical approach) daripada pendekatan yang lain. Metode penelitiannya mencakup sumber data, pengumpulan data, dan analisis data.

\section{Hasil dan Pembahasan}

\section{Pembinaan}

Pembinaan berasal dari kata bina, yang mendapat imbuhan pe-an, sehingga menjadi kata pembinaan.Pembinaan adalah usaha, tindakan, dan kegiatan yang dilakukan secara efisien dan efektif untuk memperoleh hasil yang lebih baik. Pembinaan merupakan proses, cara membina dan penyempurnaan atau usaha tindakan dan kegiatan yang dilakukan untuk memperoleh hasil yang lebih baik. Pembinaan pada dasarnya merupakan aktivitas atau kegiatan yang dilakukan secara sadar, berencana, terarah, dan teratur secara bertanggung jawab dalam rangka penumbuhan, peningkatan dan mengembangkan kemampuan serta sumber-sumber yang tersedia untuk mencapai tujuan.

Menurut Mangunhardjana untuk melakukan pembinaan ada beberapa pendekatan yang harus diperhatikan oleh seorang pembina, antara lain: a) Pendekatan informative (informative approach), yaitu cara menjalankan program dengan menyampaikan informasi kepada peserta didik. Peserta didik dalam pendekatan ini dianggap belum tahu dan tidak punya pengalaman. b) Pendekatan partisipatif (participative approach), dimana dalam pendekatan ini peserta 
didik dimanfaatkan sehingga lebih ke situasi belajar bersama. Pendekatan eksperiansial (experienciel approach), dalam pendekatan ini menempatkan bahwa peserta didik langsung terlibat di dalam pembinaan, ini disebut sebagai belajar yang sejati, karena pengalaman pribadi dan langsung terlibat dalam situasi tersebut.

Dengan demikian dapat disimpulkan bahwa pembinaan adalah suatu proses belajar dalam upaya mengembangkan dan meningkatkan pengetahuan, keterampilan dan sikap yang bertujuan untuk lebih meningkatkan kemampuan seseorang atau kelompok.

Pembinaan tidak hanya dilakukan dalam keluarga dan dalam lingkungan sekolah saja, tetapi diluar keduanya juga dapat dilakukan pembinaan.Pembinaan dapat dilakukan melalui kegiatan ekstrakurikuler maupun intrakurikuler yang ada di sekolahan dan lingkungan sekitar.

\section{Akhlak}

Pengertian akhlak dapat ditinjau dari dua segi yaitu dari segi bahasa dan istilah. Menurut bahasa akhlak berasal dari kata bahasa Arab yaitu jamak dari khilqun atau khuluqun yang artinya budi pekerti, adat kebiasaan, perangai, muru'ah atau segala sesuatu yang sudah menjadi tabi'at. Adapun secara istilah, ibn Miskawaih secara singkat mengatakan akhlak adalah :"sifat yang tertanam dalam jiwa yang mendorong untuk melakukan perbuatan tanpa memerlukan pemikiran dan pertimbangan".

Akhlak artinya sifat atau perilaku yang terdiri dari akhlak terpuji (mahmudah) dan akhlak tercela (madzmumah). Akhlak terpuji tersebut dapat menjadikan dirinya disukai dan dicintai orang lain, sehingga dirinya akan menjadi teladan kebaikan bagi orang lain, sedangkan akhlak terceela dapat menjadikan dirinya tidak disenangi oleh oranglain. Membiasakan sifat tanggung jawab, adil dan bijaksana dalam kehidupan sehari-hari, sebagai manusia kita harus berani mempertanggung jawabkan segala perbuatan di hadapan diri sendiri, keluarga, dan Allah SWT.

Definisi akhlak juga dapat dirujuk dari beberapa pengertian para tokoh, seperti alGazali, Abdullah Darroz, Ibnu Maskawaih, dan Ahmad Amin. Menurut Imam Al-Gazali, akhlak adalah sifat yang tertanam dalam jiwa yang dapat menimbulkan perbuatan-perbuatan dengan mudah tanpa melalui pemikiran dan pertimbangan. Menurut Abdullah Darroz, akhlak adalah suatu kekuatan dalam kehendak yang mantap serta membawa kecenderungan terhadap pemilihan pada pihak yang benar (akhlak yang baik) dan/atau pihak yang jahat (akhlak yang buruk).

Menurut Ahmad Amin, akhlak adalah kebiasaan kehendak, yang berarti bahwa bila kehendak itu membiasakan sesuatu maka kebiasaan tersebut disebut akhlak. Akan tetapi, Ahmad Amin memberikan pengertian yang lain, akhlak ialah menangnya keinginan dari beberapa keinginan manusia secara langsung dan berturut-turut.Dinamakan orang yang (berakhlak) baik adalah orang yang menguasai keinginan baik dengan langsung dan berturut- 
turut, sebaliknya orang yang (berakhlak) buruk ialah orang yang menguasai keinginan buruk dengan langsung dan berturut-turut.Sedangkan menurut Ibn Maskawaih, akhlak adalah suatu keadaan yang melekat pada jiwa manusia, yang berbuat dengan mudah, tanpa melalui pemikiran atau pertimbangan.

Berdasarkan definisi akhlak di atas, penulis menganggap pengertian akhlak menurut alGazali memiliki kesamaan dengan Ibn Maskawaih.Keduanya sama-sama menyebutkan akhlak sebagai keadaan yang melekat pada jiwa, yang menjadikan manusia dapat berbuat dengan mudah, tanpa melalui pemikiran dan pertimbangan.Adapun pengertian akhlak menurut Ahmad Amin bersifat lebih umum, yakni akhlak ialah kehendak yang dibiasakan.Sehingga kalau kehendaknya membiasakan perbuatan, dan perbuatannya menjadi terbiasa, maka dinamakan akhlak pula.

Akhlak pada dasarnya melekat dalam diri seseorang, bersatu dengan perilaku atau perbuatan.Jika perilaku yang melekat itu buruk, maka disebut akhlak yang buruk atau akhlak mazmumah.Sebaliknya, apabila perilaku tersebut baik disebut akhlak mahmudah.

Akhlak merupakan perilaku yang tampak (terlihat) dengan jelas, baik dalam kata-kata maupun perbuatan yang memotivasi oleh dorongan karena Allah. Namun demikian, banyak pula aspek yang berkaitan dengan sikap batin ataupun pikiran, seperti akhlak diniyah yang berkaitan dengan berbagai aspek, yaitu pola perilaku kepada Allah, sesama manusia, dan pola perilaku kepada alam. Akhlak islam dapat dikatakan sebagai aklak yang islami adalah akhlak yang bersumber pada ajaran Allah dan Rasulullah.

Akhlak islami ini merupakan amal perbuatan yang sifatnya terbuka sehingga dapat menjadi indikator seseorang apakah seorang muslim yang baik atau buruk. Akhlak ini merupakan buah dari akidah dan syariah yang benar.Secara mendasar, akhlak ini erat kaitannya dengan kejadian manusia yaitu khaliq (pencipta) dan makhluq (yang diciptakan).Rasulullah diutus untuk menyempurnakan akhlak manusia yaitu untuk memperbaiki hubungan makhluq (manusia) dengan khaliq (Allah Ta'ala) dan hubungan baik antara makhluq dengan makhluq.

Pendidikan akhlak tidak terlepas dari pendidikan agama yang keduanya harus dilaksanakan dalam praktek hidup, pengalaman sehari-hari perlakuan dan percontohan di samping pengertian tentang agama dan moral. Lingkungan keluarga merupakan lingkungan pendidikan yang pertama, karena dalam keluarga dinilah akan pertama-tama mendapatkan didikan dan bimbingan. Juga dikatakan lingkungan yang utama, karena sebagian besar dari kehidupan anak adalah di dalam keluarga, sehingga pendidikan yang paling banyak diterima oleh anak adalah dalam keluarga (Zakiyah Daradjat, 1995 : 24).

Ibnu Qayyim (dalam Muh. Suwaid 2003:19), anak akan tumbuh menurut apa yang di biasakan oleh pendidiknya ketika kecil. Jika sejak kecil anak terbiasa marah, keras kepala, tergesa-gesa dan mudah mengikuti hawa nafsu, serampangan, tamak dan seterusnya, maka 
akan sulit baginya untuk memperbaiki dan menjauhi hal-hal itu ketika dewasa. Seperti yang kita ketahui bahwa seorang anak dilahirkan dalam keadaan fitrah tanpa noda dan dosa, seperti sehelai kain putih yang belum mempunyai motif dan warna. Oleh karena itu, orangtualah yang akan memberikan warna terhadap kain putih tersebut. Hal ini sesuai dengan hadits Nabi Saw: ("Setiap anak dilahirkan dalam keadaan fitrah, maka orangtuanyalah yang menjadikanya sebagai Yahudi, Nasrani atau Majusi" ( H.R. Bukhori).

\section{Anak}

Anak dalam perspektif islam merupakan amanah dari Allah sebagaimana dijelaskan dalam Firman Allah swt Qs. Asy-Syuura ayat: 49

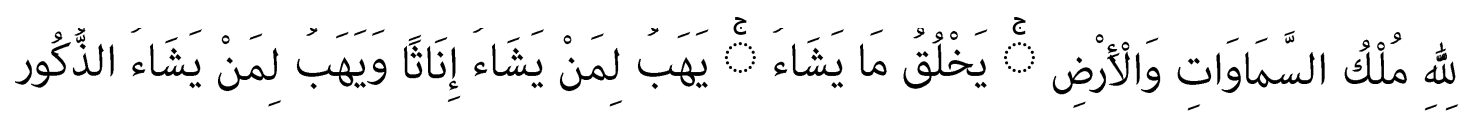

"Kepunyaan Allah-lah kerajaan langit dan bumi, Dia menciptakan apa yang Dia kehendaki.Dia memberikan anak-anak perempuan kepada siapa yang Dia kehendaki dan memberikan anak-anak lelaki kepada siapa yang Dia kehendaki." (Q.S Asy-Syuura: 49)

Kata anak dalam al-qur'an disebutkan dengan istilah "athfal" dengan pengertian anak mulai lahir sampai usia baligh, seperti yang dijelaaskan dalam Qs. An-Nur ayat 59:

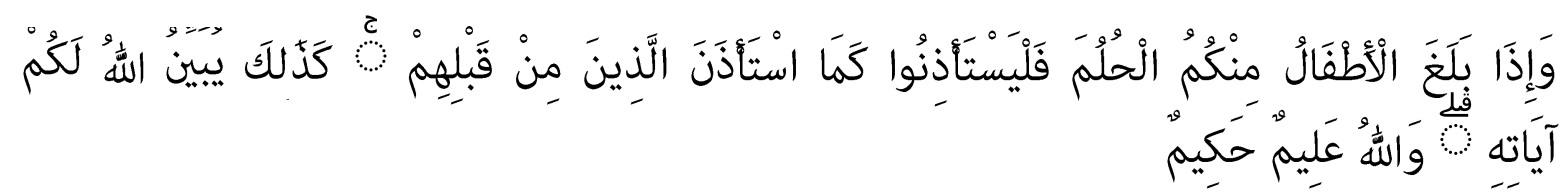

"Dan apabila anak-anakmu telah sampai umur balig, maka hendaklah mereka meminta izin, seperti orang-orang yang sebelum mereka meminta izin.Demikianlah Allah menjelaskan ayat-ayat-Nya.Dan Allah Maha Mengetahui lagi Maha Bijaksana." (Q.S AnNur: 59)

Meskipun anak dalam kandungan masih abstrak, namun dalam pendidikan itu sudah bisa dimulai dengan memiliki keterkaitan pada ibu yang mengandungnya (pendidikan prenatal). Sedangka secara nyata, pendidikan islam tentanganak bayak diarahkan pada pendidikan (setelah kelahiran), tepatnya dimulai sejak penamaan anak.

Dari penjelasan di atas dapat di ambil kesimpulan bahwa pembinaan akhlak sangat penting dilakukan sedini mungkin kepada anak karena anak usia dini akan cepat menangkap serta menirukan apa yang dipelajarinya, sehingga orangtua maupun guru harus cermat dalam membina akhlak anak agar mmenjadi anak yang berbuti pekerti luhur dan berakhlak mulia.

\section{Daftar Pustaka}

Habibah, S. (2015). Akhlak dan Etika Dalam Islam. Jurnal Pesona Dasar, 1 (4), 73. didapat dari http://jurnal.unsyiah.ac.id/ PEAR/article/ download/7527/6195 
Herawati, (2017). Pendidika akhlak bagi anak usiadini. 3 (2), 126=127. Didapat dari http://jurnal.ar-raniry.ac.id/index.php /bunayya/article/ download/1703/ 1241

Marzuki.(2009). Pembinaan Akhlak Mulia Dalam Berhubungan Antar Sesama Manusia Dalam Perspektif Islam.Jurnal bumanika. 9. 1 26-27. Didapat dari https://journal.uny.ac.id/index.php/humanika /article /view/3781

Mustofa, (2014).Akhlak mulia dalam pandangan masyarakat.Jurnal pendidikan Islam.8 (2), 267. Didapat dari http://journal.Walisongo .ac.id/index.hp/ Nadwa/article/ downlo ad / $581 / 528$.

Nasution, K.N, \& Abadi, A.M. Pelaksanaan Pembelajaran Pendidikan Akidah Akhlak. Jurnal Tunas Bangsa.32. Didapat dari http://download.portalgaruda. org/article. php? Article = $530771 \&$ val $=10891 \&$ title $=$ Pelaksanaan $\% 20$ pembelajaran $\% 20$ pendidikan $\% 20$ akidah $\% 2$ 0akhlak

Nawawi, M. (2013).Konsep Pendidikan Akhlak Anak Menurut Al-Ghazali Dalam Kitab Ayyuhal-Walad. Jurnal Skripsi. 10-13. Didapat dari http://digilib.uinsuka.ac.id/10025/1/BAB\%20I\%2C\%20IV\%2C\%20 DAFTAR \% 20PUSTAKA.pdf

Sulthoni, M. (2015).Pendidikan Akhlak Bagi Anak Usia Dini (3 Sampai 6 Tahun) Di Lingkungan Keluarga Menurut Imam Alghazali. Jurnal skripsi. 1. Didapat dari https:// core.ac.uk / download/pdf/ 147421636. pdf.

Undang-undang Republik Indonesia Nomor 20 Tahun 2003 Tentang Sistem Pendidikan Nasional. 2016

Wulandari, D. (2009). Pendidikan Akhak Di Taman Kanak-Kanak.Jurnal Skripsi. 3. Didapat dari http:// eprints.ums.ac.id/3539/2/ G000050039. pdf

Wati, D.C. (2017). Penanaman Nilai-nilai Religius di Sekolah Dasar untuk Penguatan Jiwa Profetik Siswa.Jurnal Prosiding Konferensi Nasional Kewarganegaraan Iii.60. Didapat dari https://www. researchgate. net/publication/ 324771433

Aryani, N. (2015). Konsep Pendidikan Anak Usia Dini Dalam Perspektif Pendidikan Islam. Jurnal Kependidikan Islam.1, 2. 213-214. DOI: 10.18592/khazanah.v14i2.1634. 